\title{
T Cell Proliferative Response Induced by DNA Topoisomerase I in Patients with Systemic Sclerosis and Healthy Donors
}

\author{
Masataka Kuwana, ${ }^{*}$ Thomas A. Medsger, Jr., ${ }^{\star}$ and Timothy M. Wright ${ }^{\star \star}$ \\ ${ }^{*}$ Division of Rheumatology and Clinical Immunology, Department of Medicine; and ${ }^{\ddagger}$ Department of Molecular Genetics
} and Biochemistry, University of Pittsburgh School of Medicine, Pittsburgh, Pennsylvania 15261

\begin{abstract}
The in vitro $T$ cell proliferative response to DNA topoisomerase I (topo I) was examined in 26 systemic sclerosis (SSc) patients with anti-topo I antibody, 10 SSc patients without anti-topo I antibody, and 21 healthy donors. Using recombinant fusion proteins encompassing the entire human topo I amino acid sequence, a topo I-specific proliferative response was detected in PBMC cultures from 25 (96\%) anti-topo I-positive SSc patients, 4 (40\%) anti-topo I-negative SSc patients, and $13(62 \%)$ healthy donors. Molecular typing at MHC class II loci revealed that all SSc patients and healthy donors having either DRB1*1501,2 (DR15), DRB1 *1101,3,4 (DR11), or DRB1 *07 (DR7) were responders. Characterization of the topo $I$-induced $T$ cell proliferative response showed that $(a)$ the responding cells were CD4+ T cells; $(b)$ antigen-presenting cells were necessary for the response; $(c)$ the response was restricted by HLA-DR, and to a lesser extent by HLA-DQ; and $(d)$ the estimated frequency of the responding $T$ cells determined by limiting dilution analysis was 1/9,277-1/24,853. PBMC cultures from anti-topo I-positive SSc patients showed a high $T$ cell proliferative response after only $3 \mathrm{~d}$ of culture with topo I. Anti-topo I-negative SSc patients and healthy donors had no proliferative response after $3 \mathrm{~d}$, but did respond after $7 \mathrm{~d}$ of culture. $\mathrm{T}$ cell proliferative responses to six truncated topo I fragments tested individually showed different patterns of $T$ cell proliferation that were dependent upon the responder's HLA-DR alleles. These results indicate that $T$ cells reactive with topo $I$ are components of the normal $T$ cell repertoire, and that the topo $I-$ specific $T$ cell proliferative response is not associated with the presence or absence of SSc or anti-topo I antibody, but is restricted by MHC class II alleles. (J. Clin. Invest. 1995. 96:586-596.) Key words: autoantibody $\bullet$ antinuclear antibody $\bullet$ HLA $\bullet T$ cell tolerance $\cdot$ cryptic epitope
\end{abstract}

Address correspondence to Timothy M. Wright, MD, Division of Rheumatology and Clinical Immunology, University of Pittsburgh School of Medicine, E1157 Biomedical Science Tower, Pittsburgh, PA 15261. Phone: 412-624-9028; FAX: 412-648-7047.

Received for publication 19 January 1995 and accepted in revised form 22 February 1995.

1. Abbreviations used in this paper: APC, antigen-presenting cell; MBP, maltose-binding protein; SI, stimulation index; snRNP, small nuclear ribonucleoprotein; SSc, systemic sclerosis; topo I, DNA topoisomerase I.

J. Clin. Invest.

(C) The American Society for Clinical Investigation, Inc. 0021-9738/95/07/0586/11 \$2.00

Volume 96, July 1995, 586-596

\section{Introduction}

Systemic sclerosis (scleroderma; or $\mathrm{SSc}^{1}$ ) is an autoimmune disease characterized by microvascular damage and fibrosis of the dermis and internal organs (1). One prominent immunologic abnormality of SSc is the presence of serum antinuclear antibody, which is found in $>90 \%$ of patients (1). The autoantigens to which these antibodies bind include DNA topoisomerase I (topo I); centromere/kinetochore; RNA polymerases I, II, and III; U3 ribonucleoprotein; and Th ribonucleoprotein (15). It is well established that each distinctive SSc-related antinuclear antibody is closely associated with its own unique combination of clinical features (1-5). These findings suggest that the production of SSc-related antinuclear antibodies may be related to the fundamental disease process of SSc.

Antinuclear antibodies directed against topo I (6), formerly termed Scl-70 (7), are detected in the sera from $\sim 20-30 \%$ of SSc patients (8). Anti-topo I antibody is specific to SSc sera and is associated with diffuse cutaneous involvement, peripheral vascular disease, and pulmonary interstitial fibrosis $(4,5)$. Human autoimmune sera containing anti-topo I antibodies recognize multiple B cell epitopes on the topo I molecule (9), suggesting that anti-topo I antibody production is an antigendriven process. T cell "help" is presumed to be required for the production of this autoantibody since topo I is a protein antigen, anti-topo I antibody is usually present in SSc sera at high titer $(6,10)$, and the most abundant anti-topo I antibody isotypes are IgG and IgA (10). Recent MHC class II gene typing analyses of anti-topo I-positive SSc patients showed that the presence of serum anti-topo I antibody was associated with specific MHC class II alleles. In two studies examining this relationship in North American populations, anti-topo I antibody was associated with the broad specificity of DR11 and DQ3 (11), or more specifically specific DR11 and DQ3 suballeles DRB $1 * 1104$ and DQB $1 * 0301$ (12). In a study of Japanese SSc patients, anti-topo I antibody was associated with DRB1*1502 and DQB1*0601 (13). Furthermore, we found that anti-topo I antibody titer and reactivities against certain $B$ cell epitopes on topo I were related to amino acid sequences shared among several HLA-DR molecules (13). These observations strongly suggest that an interaction of MHC class II molecules and autoreactive $T$ cells via the $T$ cell receptor plays an important role in the anti-topo I antibody production in SSc patients. Although $\mathrm{T}$ cell responses to self-proteins have been well characterized in organ-specific autoimmune diseases such as multiple sclerosis and autoimmune thyroid diseases, only a limited number of such analyses have been performed for systemic autoimmune diseases. Moreover, all of these latter studies examined autoantigen-specific $T$ cell response in patients with SLE or mixed connective tissue disease (14-16), and an investigation of autoantigen-specific $\mathrm{T}$ cell responses has not performed in SSc patients. One potential reason for this may be 
the difficulty in obtaining a sufficient amount of highly purified soluble autoantigen for such studies. Recently, we have prepared recombinant fusion proteins encompassing the entire topo I molecule and have used these recombinant topo I proteins to develop an anti-topo I antibody ELISA (10). In the present study, these recombinant proteins were used to examine the topo I-specific $\mathrm{T}$ cell proliferative response in SSc patients with or without serum anti-topo I antibody and in healthy donors.

\section{Methods}

Patients and healthy donors. 26 SSc patients with serum anti-topo I antibody ( 19 women and 7 men; age 28-69 yr, mean $48 \mathrm{yr}$ ), $10 \mathrm{SSc}$ patients without serum anti-topo I antibody ( 8 women and 2 men; age 28-68 yr, mean $43 \mathrm{yr}$ ), and 21 healthy donors ( 10 women and 11 men; age $26-60 \mathrm{yr}$, mean $39 \mathrm{yr}$ ) were included in this study. All SSc patients visited the Scleroderma Clinic, Division of Rheumatology and Clinical Immunology, University of Pittsburgh School of Medicine for followup evaluation during January through May, 1994, and fulfilled the American Rheumatism Association preliminary classification criteria for SSc (17). Anti-topo I-positive SSc patients included 23 North American Caucasians, 2 North American Blacks, and one Japanese, whereas all 10 anti-topo I-negative SSc patients were North American Caucasians. Healthy donors consisted of 19 North American Caucasians and 2 Japanese living in the Pittsburgh area.

Clinical and laboratory findings were prospectively collected on all anti-topo I-positive SSc patients. These included disease duration at the time of the analysis, organ involvement (peripheral vasculature, skin, joint/tendon, muscle, intestine [esophagus and small bowel], lung, heart, and kidney), and previous and current medications (corticosteroids, immunosuppressive agents, and D-penicillamine). Disease duration was measured from the time of onset of the first symptom attributable to SSc. SSc disease classification (limited or diffuse cutaneous involvement variant of SSc) was determined by one of the authors ( $T$. A. Medsger, Jr.) according to the previously published criteria (1) Criteria for organ involvement were based on our definition reported elsewhere (2).

Anti-topo I antibody assays. Anti-topo I antibody was analyzed using serum samples obtained at the time of PBMC isolation for the cell proliferation assay. Serum anti-topo I antibody was assayed by three different methods including double immunodiffusion (Ouchterlony) using rabbit thymus extract as an antigen (9), immunoprecipitation using ${ }^{35} \mathrm{~S}$-labeled HeLa cell extract $(3,18)$, and ELISA using recombinant topo I (10). The levels of IgG, IgA, IgM, and "total" (total of IgG, IgA, and IgM isotypes ) anti-topo I antibodies were determined by quantitative ELISA (10). Sera from all anti-topo I-positive SSc patients were confirmed to be positive by all three methods, and those from all anti-topo I-negative SSc patients and healthy donors were confirmed to be negative by all three methods.

Antigens. Six truncated soluble recombinant topo I fusion proteins (Fig. 1) were prepared as described (10). These included F3 (amino acids 1-93 of 765 amino acids of topo I), F4 (amino acids 43-224), F5 (amino acids 209-386), F6 (amino acids 363-563), F7 (amino acids 541-765), and F11 (amino acids 658-765). Briefly, portions of the topo I cDNA prepared by restriction endonuclease digestion were subcloned in frame into the pMAL-c2 expression vector (New England Biolabs, Beverly, MA) and expressed in Escherichia coli as maltosebinding protein (MBP) -topo I fusion proteins. After affinity purification using amylose resin chromatography (19), fusion proteins were dialyzed against Tris-buffered saline (20 mM Tris/ $\mathrm{HCl}, 140 \mathrm{mM} \mathrm{NaCl}$, $\mathrm{pH} 7.4$ ) and sterilized by passage through $0.22-\mu \mathrm{m}$ pore-size syringe filters. To minimize proteolytic degradation, all recombinant fusion proteins were immediatley aliquoted and stored at $-80^{\circ} \mathrm{C}$ until use. SDSPAGE analyses showed that the purity of all recombinant proteins was $>95 \%$, and all recombinant proteins except for F4 contained intact recombinant protein and minimal degradation fragments. F4 was prone

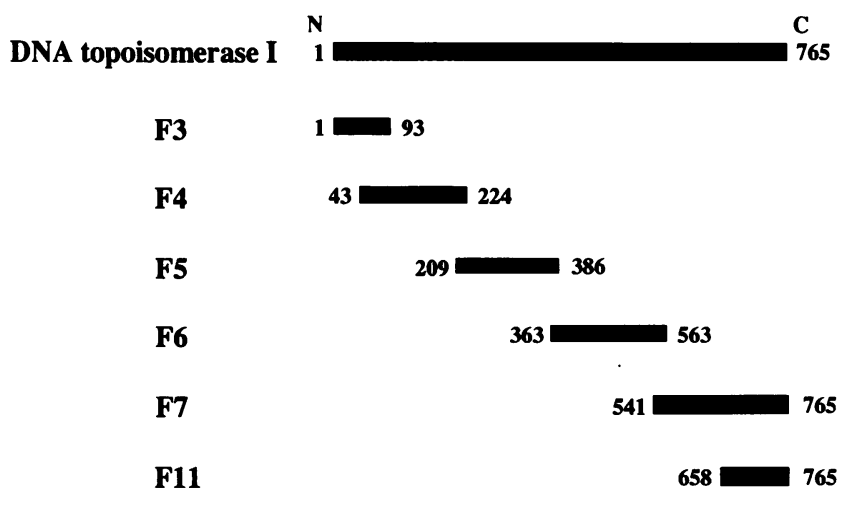

Figure 1. DNA topoisomerase I and truncated recombinant topo I fusion proteins $(F 3, F 4, F 5, F 6, F 7$, and $F 11)$ that were used in this study. Numbers denote the amino acid residues of the whole topo I amino acid sequence. Maltose-binding protein was fused to the $\mathrm{NH}_{2}$ terminus $(N)$ of the topo I amino acid sequence in all recombinant proteins.

to degradation, but the preparations used in these studies contained $\geq 10 \%$ intact F4 protein. Since F3-F7 encompassed the entire topo I amino acid sequence, an equimolar mixture of these five recombinant proteins was regarded as topo I, and was used to measure topo I-specific cell proliferation. MBP was expressed in $E$. coli bearing the pMAL-c2 vector without insert DNA and was affinity purified (as above) for use as a control. In some experiments, purified tetanus toxoid (Massachusetts Public Health Biological Laboratories, Boston, MA) was used as a control antigen for the cell proliferation assay.

Cell preparations. PBMC and PMN were isolated from heparinized blood using Histopaque (Sigma Chemical Co., St. Louis, MO) doubledensity gradient centrifugation. PBMC were cultured in RPMI 1640 containing 10\% FBS, $2 \mathrm{mM}$ L-glutamine, $50 \mathrm{U} / \mathrm{ml}$ penicillin, and 50 $\mu \mathrm{g} / \mathrm{ml}$ streptomycin at $37^{\circ} \mathrm{C}, 5 \% \mathrm{CO}_{2}$. PMN were stored at $-20^{\circ} \mathrm{C}$ and used as sources for genomic DNA. Monocytes, T cells, and B cells were isolated from some PBMC samples. Briefly, PBMC were cultured on plastic dishes for $1 \mathrm{~h}$, and nonadherent cells were harvested. After three washes with TBS, adherent cells were removed by scraping with a rubber policeman and served as the monocyte fraction. T cells were separated from nonadherent cells by passage through a nylon wool column. B cells were removed from the nylon wool by compression against the sides of the tubes. More than $80 \%$ of cells in the monocyte fraction were viable monocytes determined by phagocytosis of yeast. Flow cytometry revealed that the $\mathrm{T}$ cell fraction contained $>95 \% \mathrm{CD} 3+$ $\mathrm{T}$ cells, and $\mathrm{CD} 3+\mathrm{T}$ cell contamination in the $\mathrm{B}$ cell fraction was $<5 \%$. PBMC samples that were depleted of $\mathrm{CD} 4+$ or $\mathrm{CD} 8+$ cells were prepared by incubating PBMC with anti-CD4 or anti-CD8 $\mathrm{mAb}$ coupled magnetic beads (Dynal, Oslo, Norway), respectively, at $4^{\circ} \mathrm{C}$ for $1 \mathrm{~h}$, followed by magnetic removal of bead-bound cells (20). After depletion using $5.6 \times 10^{6}$ beads $/ 10^{6} \mathrm{PBMC}$, the residual CD4+ or CD8 + cells in the fractions were each $<3 \%$ by flow cytometry. In some experiments, CD4+ or CD8+ cells were depleted using serial amounts of magnetic beads (7.0 $\left.\times 10^{4}-5.6 \times 10^{6} / 10^{6} \mathrm{PBMC}\right)$.

Cell proliferation assay. PBMC ( $10^{5}$ per well) were cultured in complete medium in 96-well flat-bottomed tissue culture plates (Corning Glass Works Inc., Corning, NY). Cells were cultured for $7 \mathrm{~d}$ (or, as indicated, $3 \mathrm{~d}$ ) with medium alone, MBP ( $20 \mu \mathrm{g} / \mathrm{ml}$ ), or topo I (the mixture of $\mathrm{F} 3-\mathrm{F} 7 ; 20 \mu \mathrm{g} / \mathrm{ml}$ ) and then incubated with $1 \mu \mathrm{Ci} /$ well of $\left[{ }^{3} \mathrm{H}\right]$ thymidine during the final $16 \mathrm{~h}$ of culture. Cells were harvested and $\left[{ }^{3} \mathrm{H}\right]$ thymidine incorporation was measured by liquid scintillation counting. All cultures were carried out in triplicate, and topo I-specific cell proliferation was expressed as the stimulation index (SI), which was calculated as cpm incorporated in topo I-stimulated cultures $/ \mathrm{cpm}$ incorporated in MBP-stimulated cultures. On the basis of a previous report of antigen-specific $\mathrm{T}$ cell response (21), an $\mathrm{SI}>3$ was considered to be positive. F3, F4, F5, F6, F7, and F11 fusion proteins were also 
used separately as antigens for the cell proliferation assay. The molar concentration of each protein was equalized on the basis of the estimated molecular weight ratio (F3, F4, F5, F6, F7, and F11 were used at concentrations of $9.8,12.2,11.5,12.5,13.4$, and $10.2 \mu \mathrm{g} / \mathrm{ml}$, respectively). Fractionated cell populations (monocytes, T cells, and B cells), and the mixture of these cell populations in various ratios were also tested in the cell proliferation assay.

Secondary stimulation of PBMC was performed in some experiments. After the priming stimulation of PBMC $\left(10^{5}\right.$ per well $)$ with topo I for $7 \mathrm{~d}$, the viable cells were then cultured for $3 \mathrm{~d}$ in the presence of $50 \mathrm{U} / \mathrm{ml}$ rIL-2 (GIBCO BRL, Grand Island, NY) and irradiated (9,000 $\mathrm{rad})$ autologous EBV-transformed $B$ cell line cells $\left(5 \times 10^{4}\right)$ as antigenpresenting cells (APCs) in medium alone, or supplemented with topo I $(20 \mu \mathrm{g} / \mathrm{ml})$ or MBP $(20 \mu \mathrm{g} / \mathrm{ml})$. Proliferation was measured by incorporation of $\left[{ }^{3} \mathrm{H}\right]$ thymidine as described above.

$m A b$ blocking of topo I-specific cell proliferation. The effect on topo I-induced cell proliferation produced by blocking interactions with the MHC class II molecules was determined by the addition of mAbs specific for nonpolymorphic regions of the MHC class II molecules $(0.2$ $\mu \mathrm{g} / \mathrm{ml}$, unless indicated otherwise) to the PBMC cultures. The mAbs used were anti-HLA-DR (L243; $\left.\operatorname{IgG}_{2 \mathrm{a}}\right)$, anti-HLA-DQ ( $\left.1 \mathrm{a} 3 ; \mathrm{IgG}_{2 \mathrm{a}}\right)$, and anti-HLA-DP (B7/21; $\mathrm{IgG}_{3}$ ) (Leinco, St. Louis, MO). Purified mouse $\mathrm{IgG}_{2 \mathrm{a}}$ and $\mathrm{IgG}_{3}$ (Leinco) were used as isotype controls.

Limiting dilution analysis. To estimate the frequency of topo Iresponding $\mathrm{T}$ cells, a limiting dilution analysis was carried out according to the method of Brett et al. (22). Aliquots containing serial numbers of $\mathrm{T}$ cells $\left(10^{3}, 2.5 \times 10^{3}, 5 \times 10^{3}\right.$, and $\left.10^{4}\right)$ were cultured in 96well plates in the presence of monocytes $\left(10^{3} /\right.$ well $)$ and topo I ( $20 \mu \mathrm{g} /$ $\mathrm{ml}$ ). Each aliquot of $\mathrm{T}$ cells was dispensed in 48 wells. The wells showing an SI $>3$ were considered to be positive. On the basis of the assumption that topo I-responding cells are randomly distributed among the culture wells, the frequency of responding cells was calculated according to a Poisson distribution formula.

MHC class II allele genotyping. Genomic DNA isolated from PMN (23) was amplified by PCR using primers specific for the polymorphic exon 2 domains of the DRB1, DRB3, DRB5, DQB1, and DPB1 genes (24). MHC class II alleles were determined based on the results of RFLP of PCR-amplified products as described previously (24) with some modifications. The restriction endonuclease BsrBI (New England Biolabs) was used for discrimination of DRB $1 * 1101$ and $* 1104$.

Statistical analyses. Differences in frequencies were tested by Fisher's two-tailed exact test, and significant $P$ values were corrected by multiplying by the number of comparisons made. Mean values were compared by Student's $t$ test. Correlation coefficients $(r)$ were determined using a single regression model. Unless stated otherwise, all values represent the mean of triplicate determinations and SD are $<15 \%$ of the mean.

\section{Results}

MHC class II alleles in anti-topo I-positive SSc patients versus anti-topo I-negative SSc patients and healthy donors. The MHC class II alleles of the SSc patients and healthy donors who participated in this study are listed in Table I. Since the majority of the SSc patients examined were Caucasian, the MHC class II allele frequencies were compared among the 23 anti-topo I-positive Caucasian SSc patients, the 10 Caucasian anti-topo I-negative SSc patients, and the 19 Caucasian healthy donors. The frequencies of DRB1*1501 and DRB $1 * 1104$ alleles were increased in anti-topo I-positive SSc patients compared with anti-topo I-negative SSc patients and healthy donors, but these differences did not reach statistical significance (35\% vs. $20 \%$ and $26 \%$, and $39 \%$ vs. $10 \%$ and $11 \%$, respectively). All but one Caucasian anti-topo I-positive SSc patient (T26) had either DR15 (DRB1*1501), DR11 (DRB1*1101, $* 1103$, and $* 1104)$, or DR7 (DRB $1 * 07)$. The frequency of having one of these three alleles was significantly greater in anti-topo I-positive SSc patients compared with anti-topo Inegative SSc patients and healthy donors (96\% vs. $40 \%$ and 47\%; $P=0.001$, corrected $P=0.05$ in both comparisons). One of 2 Black anti-topo I-positive SSc patients had DRB $1 * 1501$, and one Japanese anti-topo I-positive SSc patient had DRB1*1502, another suballele of DR15. There were no associations between DR15, DR11, or DR7 and clinical findings in Caucasian SSc patients.

$P B M C$ proliferative response to topo $I$. The proliferative responses of PBMC cultured for $7 \mathrm{~d}$ with recombinant topo I expressed as $\left[{ }^{3} \mathrm{H}\right]$ thymidine incorporation and $\mathrm{SI}$ are shown in Table I. A topo I-specific response (SI $>3$ ) was detected in $25(96 \%)$ of 26 anti-topo I-positive SSc patients. Four (40\%) anti-topo I-negative SSc patients and $13(62 \%)$ healthy donors also responded to topo I. The frequency of PBMC proliferation to topo I was significantly higher in anti-topo I-positive SSc patients than those in anti-topo I-negative SSc patients and healthy donors $(P=0.001$ and 0.007 , respectively $)$, but the mean SI levels of responders were not different among these three groups (7.6 $\pm 3.3,6.0 \pm 2.6$, and 10.6 \pm 7.2 , respectively). When the MHC class II alleles of topo I responders and nonresponders were examined, it was found that all anti-topo Ipositive SSc patients, anti-topo I-negative SSc patients, and healthy donors possessing either DR15 (DRB $1 * 1501$ and *1502), DR11 (DRB1*1101, *1103, and *1104), or DR7 $(\mathrm{DRB} 1 * 07)$ were responders. The remaining responders included one Black anti-topo I-positive SSc patient with DRB $1 * 0405 / * 1001$ and three Caucasian healthy donors with DRB $1 * 1302 / * 0801$, DRB $1 * 0404 / * 0801$, and DRB1*0402/ $* 1301$. In contrast, DR1, DR3, and most alleles of DR4 and DR6 seemed to be associated with nonresponsiveness to topo I.

To confirm the presence of topo I-specific $\mathrm{T}$ cells in both anti-topo I-positive SSc patients and healthy donors, a secondary stimulation of PBMC with topo I was performed. In these experiments, topo I-dependent proliferation of primary and secondary cultures of PBMC from two anti-topo I-positive SSc patients (T1 and T4) and one healthy donor (D2) was determined. As shown in Table II, when $\left[{ }^{3} \mathrm{H}\right]$ thymidine incorporation was measured after $3 \mathrm{~d}$ of the secondary culture, topo I, but not MBP, induced proliferation of PBMC from the antitopo I-positive SSc patients and a healthy donor.

We examined the potential relationship between SI levels and clinical findings in 26 anti-topo I-positive SSc patients. Although there was no significant association of SI levels with SSc disease subset or organ involvement, a weak negative correlation between SI levels and disease duration was found $(P$ $=0.04, r=0.404$; Fig. 2 ). At the time the blood samples were obtained for the cell proliferation assay, four, seven, and two anti-topo I-positive patients were on low dose corticosteroids ( $<20 \mathrm{mg} / \mathrm{d}$ prednisolone), D-penicillamine, and azathioprine, respectively ( 2 took both corticosteroids and D-penicillamine and one took both D-penicillamine and azathioprine). There were no differences in the SI levels of PBMC from patients taking these potentially immunosuppressive agents and the remaining patients. We also found no correlation between IgG, IgA, IgM, or total anti-topo I antibody levels and the PBMC proliferative response (SI) to topo I (data not shown).

Dose dependency of topo I-induced proliferation. PBMC from three SSc patients with anti-topo I antibody were stimulated with various concentrations of topo I and MBP (0.01- 


\begin{tabular}{|c|c|c|c|c|c|c|c|c|c|c|c|c|c|}
\hline \multirow[b]{2}{*}{ No. } & \multirow[b]{2}{*}{ Race } & \multirow{2}{*}{$\begin{array}{l}\text { Disease } \\
\text { subset }\end{array}$} & \multirow[b]{2}{*}{ DR } & \multirow[b]{2}{*}{ DQ } & \multirow[b]{2}{*}{ DRB $1^{\ddagger}$} & \multirow[b]{2}{*}{ DRB3 } & \multirow[b]{2}{*}{ DQB1 } & \multirow[b]{2}{*}{ DPB1 } & \multicolumn{3}{|c|}{$\begin{array}{l}{\left[{ }^{3} \mathrm{H}\right] \text { Thymidine incorporation }} \\
(\mathrm{cpm})^{*}\end{array}$} & \multirow[b]{2}{*}{ SI } & \multirow[b]{2}{*}{ Response } \\
\hline & & & & & & & & & Medium & MBP & Topo I & & \\
\hline \multicolumn{14}{|c|}{ Anti-topo I-positive SSc patients } \\
\hline $\mathrm{T} 1$ & Caucasian & Diffuse & 2,5 & 1,3 & $1601 / 1104$ & 0202 & $0502 / 0301$ & $0402 / 1001$ & 91 & 51 & 810 & 15.9 & + \\
\hline $\mathrm{T} 2$ & Caucasian & Limited & 5 & 3 & $1101 / 1104$ & 0202 & 0301 & $0401 / 0402$ & 327 & 184 & 2631 & 14.3 & + \\
\hline T3 & Black & Diffuse & 4,10 & 1,3 & $0405 / 1001$ & - & $0501 / 0302$ & 0101/0301 & 196 & 165 & 2227 & 13.5 & + \\
\hline T4 & Caucasian & Limited & 2 & 1 & 1501 & - & 0602 & 0401 & 112 & 147 & 1582 & 10.8 & + \\
\hline T5 & Caucasian & Limited & 7 & 2,3 & $07^{8}$ & - & $0201 / 0303$ & $0901 / 1301$ & 192 & 136 & 1401 & 10.3 & + \\
\hline T6 & Caucasian & Diffuse & 2,6 & 1,3 & $1501 / 1301$ & 0202 & $0602 / 0301$ & $1001 / 1301$ & 393 & 191 & 1816 & 9.5 & + \\
\hline $\mathbf{T} 7$ & Japanese & Diffuse & 2,8 & 1,4 & $1502 / 0802$ & - & $0601 / 0402$ & 0301/0901 & 82 & 109 & 1032 & 9.5 & + \\
\hline T8 & Caucasian & Limited & 2,7 & 1,2 & $1501 / 07$ & - & $0602 / 0201$ & $0501 / 0601$ & 321 & 179 & 1511 & 8.4 & + \\
\hline $\mathrm{T} 9$ & Caucasian & Diffuse & 1,7 & 1,3 & 0101/07 & - & $0504 / 0303$ & $0401 / 1301$ & 183 & 134 & 1038 & 7.7 & + \\
\hline T10 & Caucasian & Diffuse & 1,5 & 1,3 & $0101 / 1104$ & 0202 & $0501 / 0301$ & $0401 / 1701$ & 209 & 112 & 857 & 7.7 & + \\
\hline T11 & Caucasian & Diffuse & 5,6 & 1,3 & $1103 / 1302$ & $0202 / 0301$ & $0604 / 0301$ & 0401 & 156 & 185 & 1409 & 7.6 & + \\
\hline $\mathrm{T} 12$ & Caucasian & Limited & 2,3 & 1,2 & $1501 / 0301$ & 0101 & $0602 / 0201$ & 0401 & 171 & 211 & 1417 & 6.7 & + \\
\hline T13 & Caucasian & Limited & 2,5 & 1,3 & $1601 / 1104$ & 0202 & $0502 / 0301$ & $0402 / 1701$ & 130 & 62 & 408 & 6.6 & + \\
\hline T14 & Caucasian & Diffuse & 2,7 & 1,3 & $1501 / 07$ & - & $0602 / 0303$ & $0201 / 0402$ & 185 & 151 & 967 & 6.4 & + \\
\hline T15 & Caucasian & Limited & 2,5 & 1 & $1501 / 1101$ & 0202 & $0602 / 0603$ & $0402 / 0501$ & 115 & 98 & 624 & 6.4 & + \\
\hline T16 & Caucasian & Diffuse & 5,6 & 1,3 & $1104 / 1302$ & $0202 / 0301$ & $0604 / 0301$ & $0301 / 0402$ & 762 & 1883 & 11442 & 6.1 & + \\
\hline T17 & Caucasian & Limited & 1,5 & 1,3 & $0102 / 1101$ & 0202 & $0501 / 0301$ & $0301 / 0401$ & 191 & 173 & 969 & 5.6 & + \\
\hline $\mathrm{T} 18$ & Caucasian & Limited & 4,5 & 3 & $0401 / 1103$ & 0202 & $0301 / 0302$ & 0201/0401 & 186 & 176 & 967 & 5.5 & + \\
\hline T19 & Caucasian & Limited & 2,5 & 1,3 & $1501 / 1104$ & 0202 & $0602 / 0301$ & 0401 & 306 & 297 & 1595 & 5.4 & + \\
\hline $\mathrm{T} 20$ & Caucasian & Diffuse & 5,6 & 1,3 & $1101 / 1302$ & $0202 / 0301$ & $0501 / 0301$ & $0101 / 1301$ & 151 & 201 & 1005 & 5.0 & + \\
\hline $\mathrm{T} 21$ & Caucasian & Limited & 5,6 & 1,3 & $1104 / 1302$ & 0202/0301 & $0604 / 0301$ & $0401 / 1301$ & 918 & 925 & 4440 & 4.8 & + \\
\hline $\mathrm{T} 22$ & Caucasian & Diffuse & 5,7 & 2,3 & $1104 / 07$ & 0202 & $0201 / 0301$ & $0401 / 0402$ & 95 & 76 & 341 & 4.5 & + \\
\hline $\mathrm{T} 23$ & Caucasian & Diffuse & 5,7 & 3 & $1101 / 07$ & 0202 & $0301 / 0303$ & 0401 & 225 & 158 & 676 & 4.3 & + \\
\hline $\mathrm{T} 24$ & Caucasian & Diffuse & 1,2 & 1 & $0101 / 1501$ & - & $0501 / 0602$ & $0401 / 1301$ & 171 & 158 & 648 & 4.1 & + \\
\hline T25 & Black & Diffuse & 2 & 1 & 1501 & - & 0602 & 0401 & 79 & 86 & 344 & 4.0 & + \\
\hline T26 & Caucasian & Diffuse & 4,6 & 1,3 & $0401 / 1302$ & 0301 & $0604 / 0302$ & $0901 / 1301$ & 100 & 144 & 275 & 1.9 & - \\
\hline
\end{tabular}

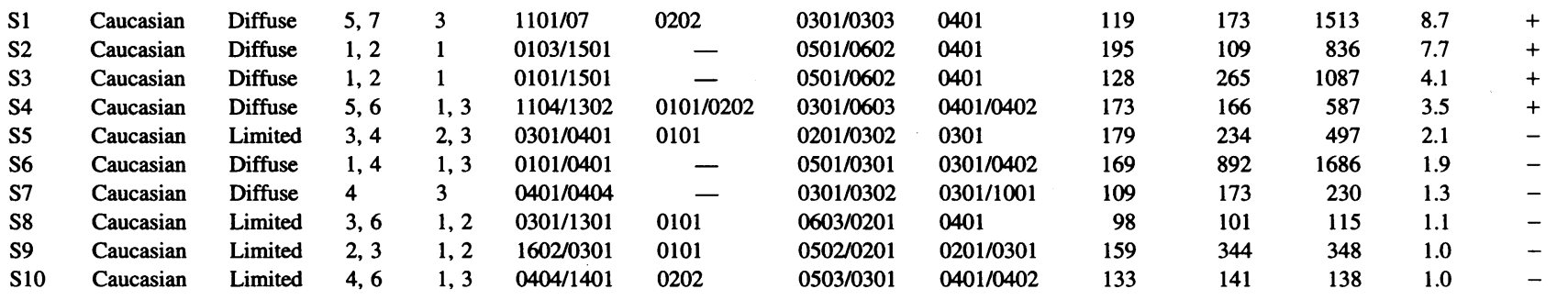

\begin{tabular}{|c|c|c|c|c|c|c|c|c|c|c|c|c|}
\hline D1 & Caucasian & 6,8 & 1,4 & $1302 / 0801$ & 0202 & $0603 / 0402$ & $0301 / 0401$ & 81 & 50 & 1391 & 27.8 & + \\
\hline D2 & Caucasian & 3,5 & 2,3 & $0301 / 1104$ & $0101 / 0202$ & 0201/0301 & $0201 / 0301$ & 266 & 434 & 5803 & 21.8 & + \\
\hline D3 & Caucasian & 4,8 & 3,4 & $0404 / 0801$ & - & $0302 / 0402$ & $0401 / 1501$ & 174 & 138 & 1819 & 13.2 & + \\
\hline D4 & Caucasian & 1,5 & 1,3 & $0101 / 1101$ & 0202 & $0501 / 0301$ & $0401 / 1701$ & 562 & 627 & 7652 & 12.2 & + \\
\hline D5 & Caucasian & 4,6 & 1,3 & $0402 / 1301$ & 0101 & $0603 / 0303$ & $0201 / 0401$ & 94 & 72 & 881 & 12.2 & + \\
\hline D6 & Caucasian & 5,7 & 3 & $1103 / 07$ & 0202 & $0301 / 0303$ & $0401 / 0402$ & 164 & 176 & 1929 & 11.0 & + \\
\hline D7 & Caucasian & 1,2 & 1 & $0103 / 1501$ & - & $0501 / 0602$ & 0401 & 307 & 525 & 4309 & 8.2 & + \\
\hline D8 & Caucasian & 2,5 & 1,3 & $1501 / 1101$ & 0202 & $0602 / 0301$ & 0201/0401 & 331 & 239 & 1817 & 7.6 & + \\
\hline D9 & Caucasian & 6,7 & 1,2 & $1301 / 07$ & 0101 & $0603 / 0201$ & $0201 / 0402$ & 643 & 814 & 5011 & 6.2 & + \\
\hline D10 & Caucasian & 2,5 & 1,3 & $1501 / 1101$ & 0202 & $0602 / 0301$ & $0101 / 0201$ & 204 & 300 & 1793 & 6.0 & + \\
\hline D11 & Caucasian & 2,5 & 1,3 & $1501 / 1104$ & 0202 & $0602 / 0301$ & $0401 / 0402$ & 160 & 162 & 797 & 4.9 & + \\
\hline D12 & Japanese & 2,6 & 1 & $1502 / 1405$ & 0202 & $0503 / 0601$ & $0501 / 0901$ & 135 & 180 & 648 & 3.6 & + \\
\hline D13 & Caucasian & 1,2 & 1 & $0101 / 1501$ & - & $0501 / 0602$ & $0401 / 1401$ & 224 & 185 & 625 & 3.4 & + \\
\hline D14 & Caucasian & 4,6 & 1,3 & $0407 / 1301$ & 0202 & $0603 / 0302$ & $0402 / 1901$ & 150 & 163 & 342 & 2.1 & - \\
\hline D15 & Caucasian & 3,10 & 1,3 & $0301 / 1001$ & 0101 & $0501 / 0302$ & 0401 & 64 & 58 & 62 & 1.1 & - \\
\hline D16 & Caucasian & 4 & 3 & 0401 & - & 0302 & $0201 / 0301$ & 92 & 94 & 95 & 1.0 & - \\
\hline D17 & Caucasian & 3 & 2,3 & 0301 & 0101 & $0201 / 0302$ & $0101 / 0401$ & 141 & 180 & 164 & 0.9 & - \\
\hline D18 & Caucasian & 1,6 & 1 & $0101 / 1302$ & 0301 & $0501 / 0604$ & $0301 / 0401$ & 140 & 172 & 157 & 0.9 & - \\
\hline D19 & Caucasian & 3,4 & 2,3 & $0301 / 0404$ & 0101 & $0201 / 0302$ & $0101 / 0301$ & 163 & 205 & 151 & 0.7 & - \\
\hline D20 & Japanese & 8,9 & 1,3 & $0803 / 0901$ & - & $0601 / 0303$ & 0501 & 86 & 163 & 121 & 0.7 & - \\
\hline D21 & Caucasian & 6 & 1 & 1302 & 0301 & $0501 / 0604$ & $0401 / 1401$ & 94 & 92 & 55 & 0.6 & - \\
\hline
\end{tabular}

* Results are expressed as the mean of triplicates (SD $<20 \%$ of the mean). ${ }^{*}$ All subjects with DRB1*1501 or *1502 had DRB5*0101 or *0102, respectively; and all subjects with DRB1*1601 or *1602 had either DRB5*0201 or *0202. ${ }^{8}$ DRB $1 * 0701$ and *0702 were not discriminated in this study. 


\begin{tabular}{|c|c|c|c|c|c|c|}
\hline & \multicolumn{3}{|c|}{ Primary culture } & \multicolumn{3}{|c|}{ Secondary culture } \\
\hline & Medium & MBP & Topo I & Medium & MBP & Topo I \\
\hline & \multicolumn{3}{|c|}{ cpm } & \multicolumn{3}{|c|}{ cpm } \\
\hline Anti-to & & & & & & \\
\hline $\mathrm{T} 1$ & $184 \pm 30$ & $192 \pm 18$ & $2748 \pm 312 \quad(14.5)$ & $1816 \pm 212$ & $2060 \pm 201$ & $37080 \pm 629 \quad(18.0)$ \\
\hline $\mathrm{T} 4$ & $136 \pm 21$ & $189 \pm 24$ & $1304 \pm 96 \quad(6.9)$ & $782 \pm 41$ & $986 \pm 103$ & $10996 \pm 1329(11.1)$ \\
\hline \multicolumn{7}{|c|}{ Healthy donor } \\
\hline D2 & $369 \pm 24$ & $518 \pm 104$ & $8316 \pm 1201(16.0)$ & $1855 \pm 128$ & $1909 \pm 62$ & $28468 \pm 1024(14.9)$ \\
\hline
\end{tabular}

Results in medium alone and MBP-induced responses are shown as mean \pm SD. Results in topo I-induced responses are shown as mean \pm SD (SI). SI was calculated as cpm incorporated in topo I-stimulated cultures/cpm incorporated in MBP-stimulated cultures.

$100 \mu \mathrm{g} / \mathrm{ml}$ ). As shown in Fig. 3, the dose-response of topo Iinduced proliferation was different among these three patients. PBMC from two anti-topo I-positive SSc patients, T9 and T18, responded to $1 \mu \mathrm{g} / \mathrm{ml}$ topo I, whereas PBMC from another antitopo I-positive SSc patient, T15, required $12.5 \mu \mathrm{g} / \mathrm{ml}$ of topo I to induce proliferation. To examine differences in the doseresponse relationship of topo I-induced proliferation, PBMC from 26 responders, including 14 anti-topo I-positive SSc patients, 4 anti-topo I-negative SSc patients, and 8 healthy donors, were stimulated with two different concentrations of topo I ( 1 and $20 \mu \mathrm{g} / \mathrm{ml}$ ). The results indicated that the concentrationdependence of the topo I proliferative response was independent of the presence and duration of disease ( $\mathrm{SSc}$ ), the presence of anti-topo I antibody, and MHC class II alleles (data not shown).

Determination of cell population responding to topo $I$. T cells, monocytes, and B cells were separated from the PBMC of five anti-topo I-positive SSc patients and three healthy donors, and the topo I-induced proliferative response was measured in different combinations of these cell populations. Similar results were obtained from all individuals, and representative results from three anti-topo I-positive SSc patients and one healthy donor are shown in Fig. 4. We found that $\mathrm{T}$ cells or monocytes cultured alone did not respond to topo I. The topo I-induced proliferative response was detected in the samples in which $T$ cells and monocytes were cultured together and

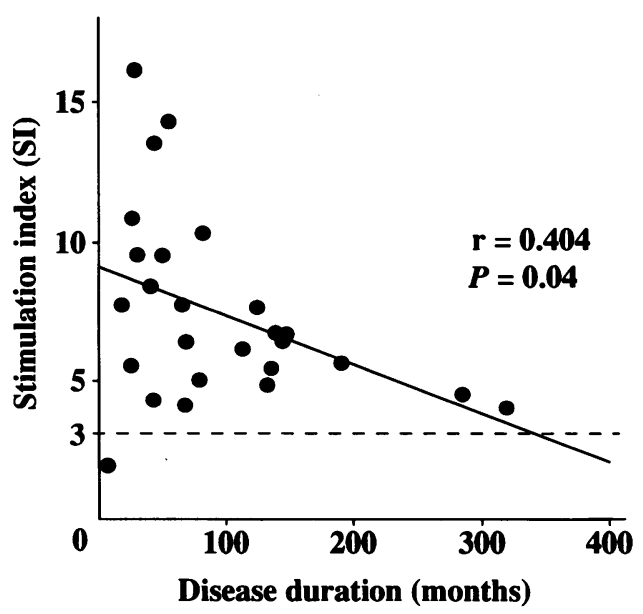

Figure 2. Negative correlation between SI induced by DNA topoisomerase I and disease duration in 26 SSc patients with anti-topo I antibody. proliferation was enhanced in a dose-dependent manner as the number of monocytes increased. Similar results were obtained when $\mathrm{B}$ cells were co-cultured with $\mathrm{T}$ cells in the absence of monocytes and B cells alone did not respond to topo I (data not shown).

To identify the $\mathrm{T}$ cell subset responding to topo I, CD4+ T cell-depleted PBMC and CD8 + T cell-depleted PBMC obtained from eight anti-topo I-positive SSc patients and four healthy donors were cultured with topo I. Representative results for four anti-topo I-positive SSc patients and two healthy donors are shown in Fig. 5. The topo I-induced proliferative response was lost when CD4+ cells were depleted, but not when $\mathrm{CD} 8+$ cells were depleted. The topo I-induced proliferative response was enhanced after depletion of $\mathrm{CD} 8+$ cells in all anti-topo I-positive SSc patients, whereas only one of four healthy donors showed response enhancement after depletion of $\mathrm{CD} 8+$ cells. Reduction of the proliferative response by CD4+ cell depletion using serial amounts of magnetic beads was dose dependent (data not shown). Taken together, these observations indicate that the responding cells are CD4+ T cells and that APCs (monocytes or B cells) are necessary for the in vitro $\mathrm{T}$ cell proliferation to topo $\mathrm{I}$.

Effect of anti-MHC class II mAbs on topo I-induced T cell

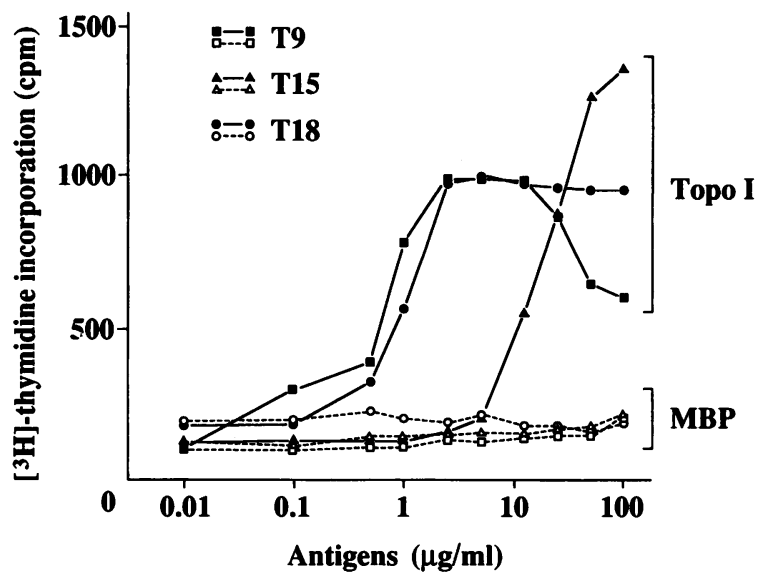

Figure 3. Dose-response of DNA topoisomerase I (Topo I)-induced PBMC proliferation in $3 \mathrm{SSc}$ patients with anti-topo I antibody ( $T$, $T 15$, and $T 18)$. PBMC $\left(10^{5}\right)$ were stimulated with serial concentrations $(0.01-100 \mu \mathrm{g} / \mathrm{ml}$ ) of topo I (closed symbols) or MBP (open symbols) for $7 \mathrm{~d}$. 


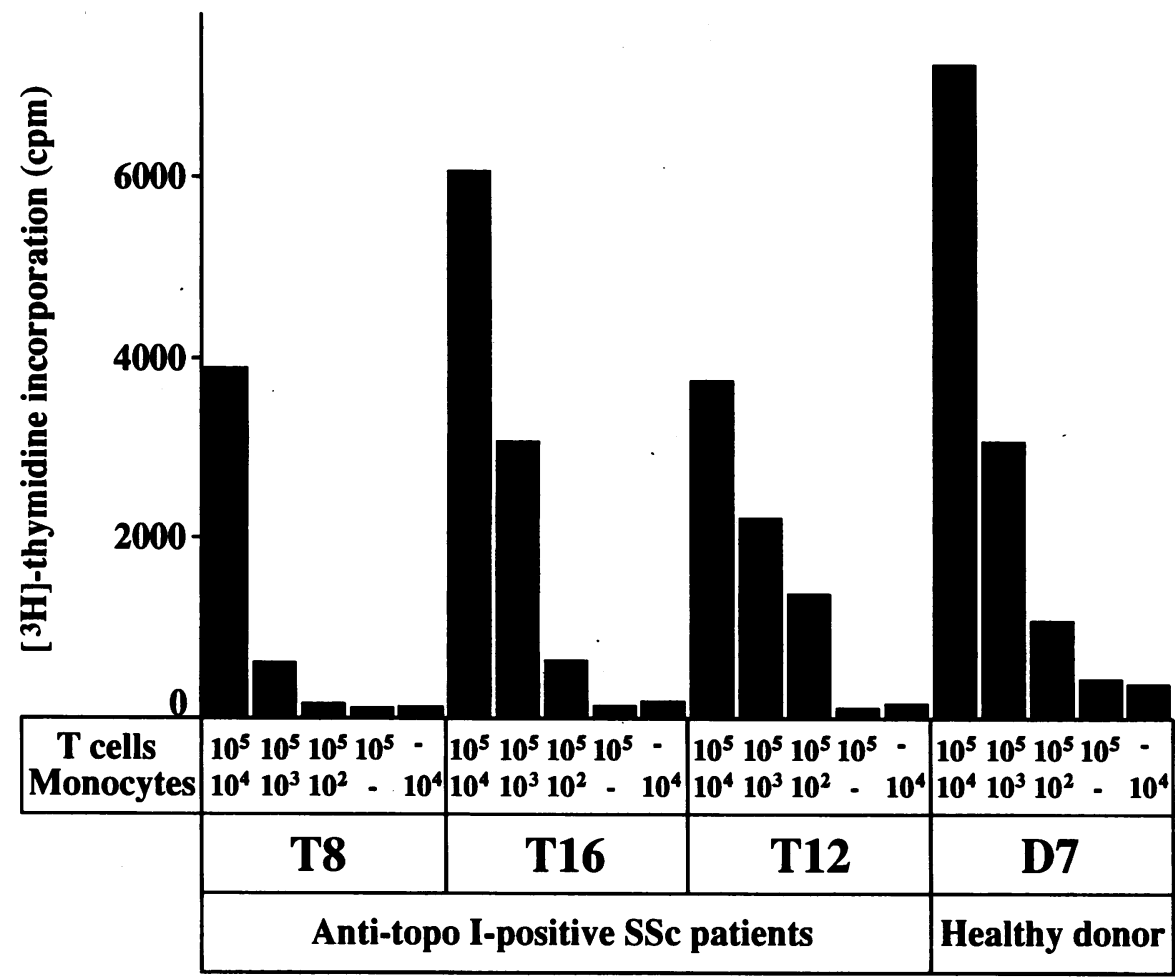

Figure 4. Topo I-induced proliferative response of $\mathrm{T}$ cells alone, monocytes alone, and the mixture of $\mathrm{T}$ cells $\left(10^{5}\right)$ and various numbers of monocytes $\left(10^{2}-10^{4}\right)$ from three SSc patients with anti-topo I antibody (T8, $T 16$, and $T 12)$ and one healthy donor (D7). Cells were stimulated with $20 \mu \mathrm{g} / \mathrm{ml}$ of topo I and cultured for $7 \mathrm{~d}$. proliferation. Specific HLA-DR $(12,13)$ and HLA-DQ (1113) alleles were reported to be associated with anti-topo I antibody. Our analysis of the $\mathrm{T}$ cell proliferative response to topo I revealed an association with HLA-DR15, DR11, and DR7. These findings suggested that HLA-DR (and/or HLA-DQ) alleles may be important in the presentation of topo I peptides to the responding $\mathrm{T}$ cells. To investigate this further, we examined the effect of MHC class II-specific mAbs on the topo I-in-

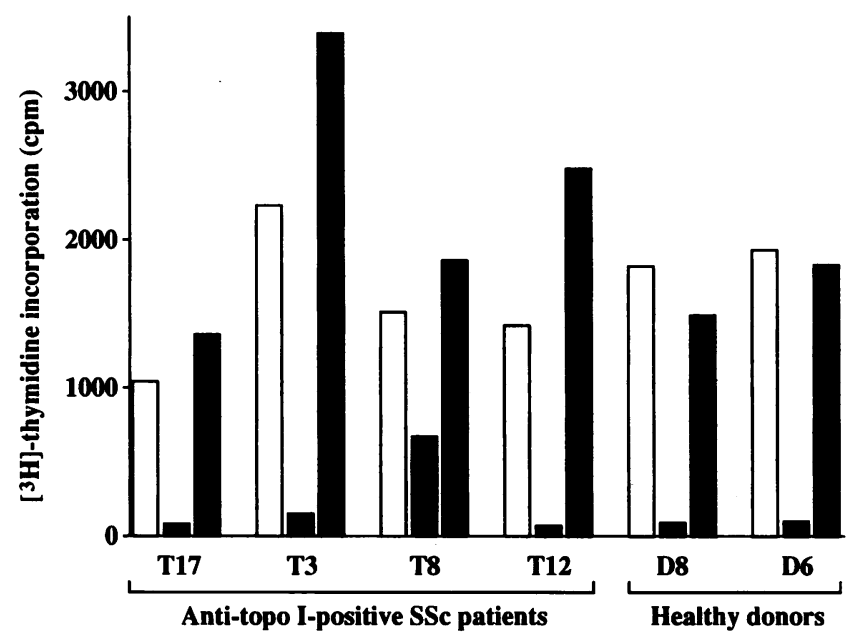

Figure 5. Topo I-induced proliferative response of PBMC (open bars), CD4+ cell-depleted PBMC (hatched bars), and CD8 + cell-depleted PBMC (solid bars) in four SSc patients with anti-topo I antibody (T17, $T 3, T 8$, and $T 12)$ and two healthy donors (D8 and D6). CD4+ cells and CD8+ cells were removed from PBMC using anti-CD4 and antiCD8 mAb-coupled magnetic beads, respectively. Cells were stimulated with $20 \mu \mathrm{g} / \mathrm{ml}$ of topo I for $7 \mathrm{~d}$. duced $\mathrm{T}$ cell proliferative response in two anti-topo I-positive SSc patients and two healthy donors. As shown in Fig. 6, the anti-HLA-DR mAb was highly effective in inhibiting topo Iinduced proliferation compared with anti-HLA-DQ and antiHLA-DP mAbs and isotype controls. Similar results were obtained in experiments using an additional five anti-topo I-positive SSc patients, two anti-topo I-negative SSc patients, and four healthy controls. Anti-HLA-DQ mAb inhibited topo Iinduced $\mathrm{T}$ cell proliferation between 20 and $42 \%$ in six (86\%) anti-topo I-positive SSc patients and three (50\%) healthy donors. The effects of various concentrations of anti-HLA-DR and anti-HLA-DQ $\mathrm{mAbs}$ and a control mouse $\operatorname{IgG}_{2 \mathrm{a}}$ on the topo-I proliferative response of PBMC from one anti-topo I-positive SSc patient (T17), are shown in Fig. 7. The topo I-induced proliferation was inhibited by anti-HLA-DR mAb in a dosedependent fashion with maximum inhibition (75\%) at $0.2 \mu \mathrm{g} /$ $\mathrm{ml}$. In contrast, the maximum inhibition by anti-HLA-DQ $\mathrm{mAb}$ was only $24 \%$ at $1 \mu \mathrm{g} / \mathrm{ml}$.

Frequency of $T$ cells responding to topo $I$. The frequency of $\mathrm{T}$ cells responding specifically to topo I was estimated by limiting dilution analysis. The frequency of topo I-reacting $\mathrm{T}$ cells ranged between $1 / 9,277$ and $1 / 24,853$ (mean $1 / 15,187$ ) in four anti-topo I-positive SSc patients (T1, T7, T12, and $\mathrm{T} 13$ ). The frequency of topo $\mathrm{I}$-reacting $\mathrm{T}$ cells was $1 / 23,755$ in one anti-topo I-negative SSc patient (S1), and 1/9,770$1 / 21,645$ (mean $1 / 15,077$ ) in five healthy donors (D3, D4, D7, $\mathrm{D} 9$, and D12). Thus, we found no differences in the frequencies of topo I-specific T cells among anti-topo I-positive SSc patients, anti-topo I-negative SSc patients, and healthy donors.

Accelerated proliferative response of topo $I$-reactive $T$ cells in anti-topo I-positive SSc patients. In order to evaluate the kinetics of the in vitro $T$ cell response to topo $I$, $T$ cell proliferation was measured on days 3 and 7 of culture with topo I fusion proteins or tetanus toxoid as a control (Table III). 

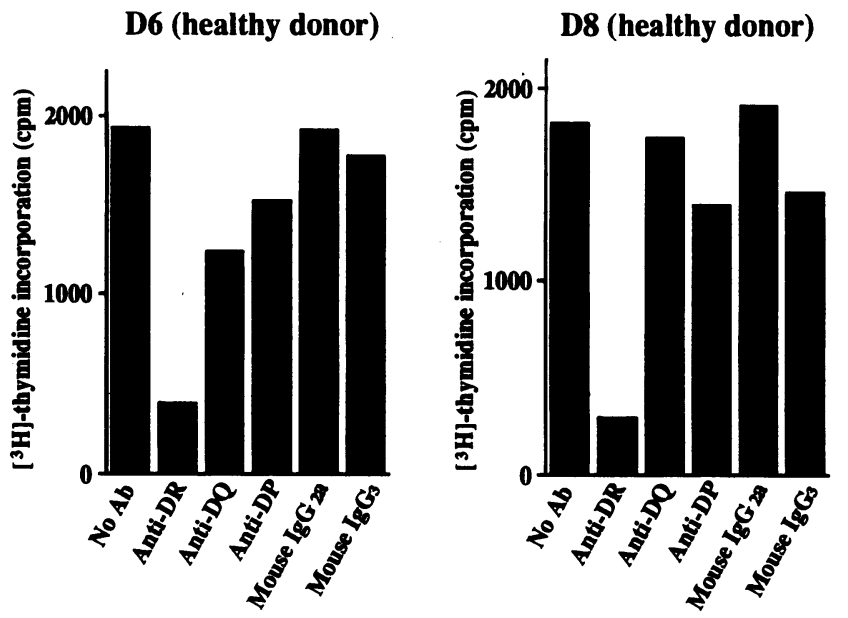

Figure 6. Effect of MHC class II-specific mAbs on topo I-induced T cell proliferation. PBMC ( $10^{5}$ per well) obtained from two SSc patients with anti-topo I antibody ( $T 8$ and $T 17$ ) and two healthy donors (D6 and D8) were stimulated with $20 \mu \mathrm{g} / \mathrm{ml}$ of topo I for $7 \mathrm{~d}$ in the presence of

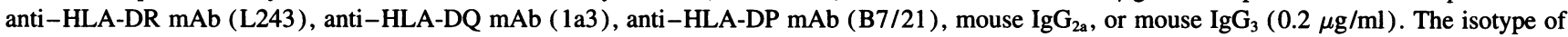
$\mathrm{L} 243$ and $1 \mathrm{a} 3$ is $\mathrm{IgG}_{2 \mathrm{a}}$, and isotype of $\mathrm{B} 7 / 21$ is $\mathrm{IgG}_{3}$.

PBMC from three anti-topo I-positive SSc patients, one antitopo I-negative SSc patient, and two healthy donors were evaluated. The anti-topo I-positive SSc patients showed a marked proliferative response at day 3 , which was higher than that observed at day 7. In contrast, T cells from the anti-topo Inegative SSc patient and the healthy donors did not respond to topo I at day 3 (SI $<3$ ), but did show proliferation at day 7 . This is similar to kinetics of the PBMC proliferative response to tetanus toxoid, a typical foreign recall antigen. The decline in the proliferative response seen in PBMC cultures from the anti-topo I-positive SSc patients from day 3 to day 7 may have been due to activation-dependent $\mathrm{T}$ cell apoptosis or early cell proliferation with exhaustion of the medium, which was not

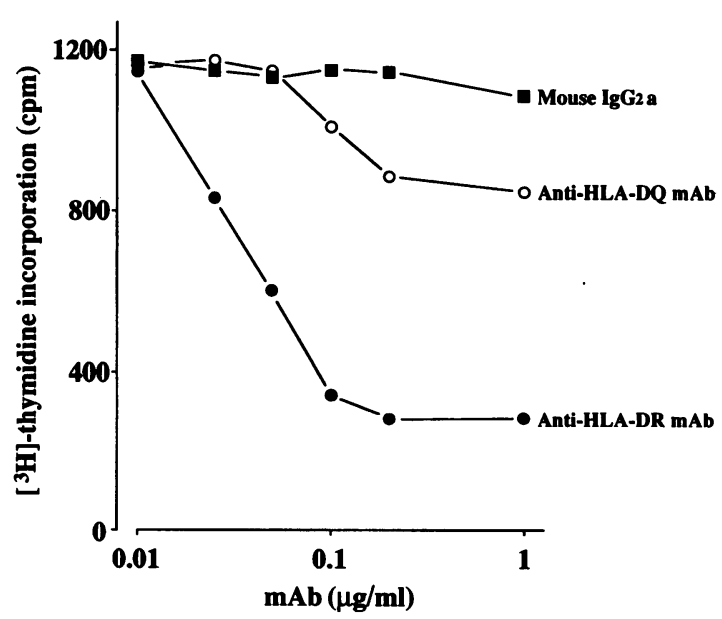

Figure 7. Dose-dependence of anti-MHC class II mAb effects on the topo I-induced PBMC proliferation in anti-topo I-positive SSc patient T17. PBMC ( $10^{5}$ per well) were stimulated with $20 \mu \mathrm{g} / \mathrm{ml}$ of topo I for $7 \mathrm{~d}$ in the presence of serial concentrations $(0.01-1 \mu \mathrm{g} / \mathrm{ml})$ of antiHLA-DR mAb (L243; •), anti-HLA-DQ mAb ( $1 \mathrm{a} 3 ; 0)$, and mouse $\mathrm{IgG}_{2} \mathrm{a}(\boldsymbol{\square})$. The values of $\left[{ }^{3} \mathrm{H}\right]$ thymidine incorporated by cells cultured with medium alone, MBP ( $20 \mu \mathrm{g} / \mathrm{ml})$, and topo I (20 $\mu \mathrm{g} / \mathrm{ml})$ were 202,182 , and $1,240 \mathrm{cpm}$, respectively. changed during this interval. The observation that PBMC from patients with anti-topo I antibody proliferated after only 3 days of culture is consistent with recent antigen exposure (in vivo "activation") in these patients, but not in anti-topo I-negative SSc patients and healthy donors.

$T$ cell proliferative responses to individual topo I recombinant proteins. The in vitro $\mathrm{T}$ cell proliferative responses to six topo I fusion proteins (F3, F4, F5, F6, F7, and F11) were examined in four anti-topo I-positive SSc patients, one antitopo I-negative SSc patient, and one healthy donor (Fig. 8). A similar pattern of topo I fragment-induced $\mathrm{T}$ cell proliferation was seen in PBMC from the anti-topo I-positive SSc patient T2 (DRB1*0101/*1104), the healthy donor D4 (DRB1*0101/1104), the anti-topo I-positive SSc patient T12 (DRB1 *1501/*0301), and the anti-topo I-negative SSc patient S2 $(\mathrm{DRB} 1 * 0103 / * 1501)$. The $\mathrm{F} 5$-induced proliferative response exceeded the responses to the other fragments in DR11positive individuals, whereas, the F6-induced response exceeded the responses against the other fragments in DR15-positive individuals. Moreover, the anti-topo I-positive SSc patient T5 homozygous for DRB1 *07 (DR7) responded to F5 and F7 without a significant response to $\mathrm{F} 6$, and anti-topo I-positive SSc patient T14 (DRB1 $* 0405 / * 1001$ ) responded to F5 and F6 without responses to the other fragments. These findings strongly suggest that the topo I fragment-induced $\mathrm{T}$ cell response is associated with HLA-DR alleles, rather than the presence or absence of SSc or anti-topo I antibody. To extend these observations, the topo $\mathrm{I}$ fragment-induced $\mathrm{T}$ cell responses were examined in an additional 20 responders including 10 anti-topo I-positive SSc patients, 2 anti-topo I-negative SSc patients, and 8 healthy donors. Assuming that the HLA-DR alleles other than DR15, DR11, and DR7 were not major determinants of the topo I-specific T cell response, we compared the topo I fragment-induced responses of individuals with DR15 (DRB1*1501), DR11 (DRB1*1101 and *1104), and DR7 (DRB1*07) who were either homozygotes or heterozygotes with non-DR15, DR11, or DR7 alleles (Fig. 9). PBMC proliferation data from seven individuals who were heterozygotes of two of DR15, DR11, and DR7 ( 3 with DR15/DR11 and 4 with 
Table III. PBMC Proliferation Induced by Topo I and Tetanus Toxoid at Days 3 and 7*

\begin{tabular}{|c|c|c|c|c|}
\hline & \multicolumn{2}{|c|}{ Topo I } & \multicolumn{2}{|c|}{ Tetanus toxoid } \\
\hline & Day 3 & Day 7 & Day 3 & Day 7 \\
\hline & cpm & cpm & cpm & cpm \\
\hline \multicolumn{5}{|c|}{ Anti-topo I-positive SSc patients } \\
\hline T1 & $1580 \pm 248(14.6)$ & $846 \pm 98 \quad(11.4)$ & $\mathrm{NT}^{\ddagger}$ & NT \\
\hline T12 & $1946 \pm 89 \quad(9.7)$ & $1317 \pm 164(6.4)$ & $306 \pm 30(1.4)$ & $7846 \pm 562(24.9)$ \\
\hline $\mathrm{T} 15$ & $1112 \pm 76$ & $608 \pm 52$ & $108 \pm 12(1.1)$ & $1826 \pm 190(16.9)$ \\
\hline \multicolumn{5}{|c|}{ Anti-topo I-negative SSc patient } \\
\hline S2 & $309 \pm 21 \cdot(2.6)$ & $894 \pm 94 \quad(8.2)$ & NT & NT \\
\hline \multicolumn{5}{|c|}{ Healty donors } \\
\hline D6 & $398 \pm 18 \quad(2.6)$ & $1918 \pm 162(10.9)$ & NT & NT \\
\hline D10 & $590 \pm 42 \quad(2.9)$ & $1764 \pm 204(5.9)$ & $291 \pm 18(1.0)$ & $6452 \pm 742(18.4)$ \\
\hline
\end{tabular}

* PBMC $\left(10^{5}\right)$ were stimulated with $20 \mu \mathrm{g} / \mathrm{ml}$ of topo I or $10 \mu \mathrm{g} / \mathrm{ml}$ of tetanus toxoid for 3 or $7 \mathrm{~d}$. Results are shown as mean \pm SD with SI in parentheses. SI was calculated as cpm incorporated in topo I-stimulated cultures/cpm incorporated in MBP-stimulated cultures for topo I-induced proliferation, or cpm incorporated in tetanus toxoid-stimulated cultures/cpm incorporated in cultures without antigen for tetanus toxoid-induced proliferation. ${ }^{\ddagger} N T$, not tested.

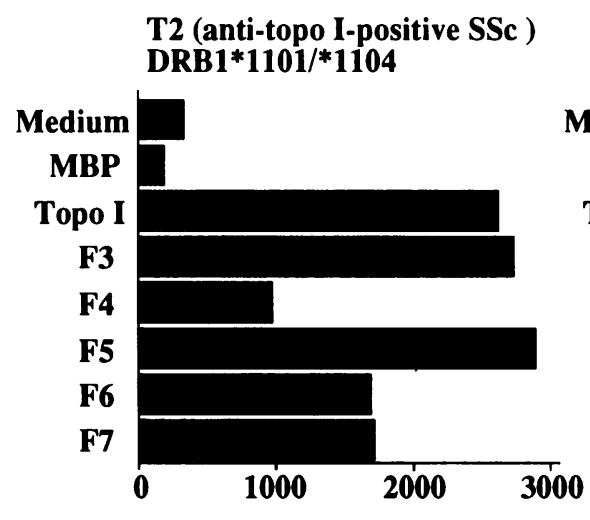

[3H]-thymidine incorporation (cpm)

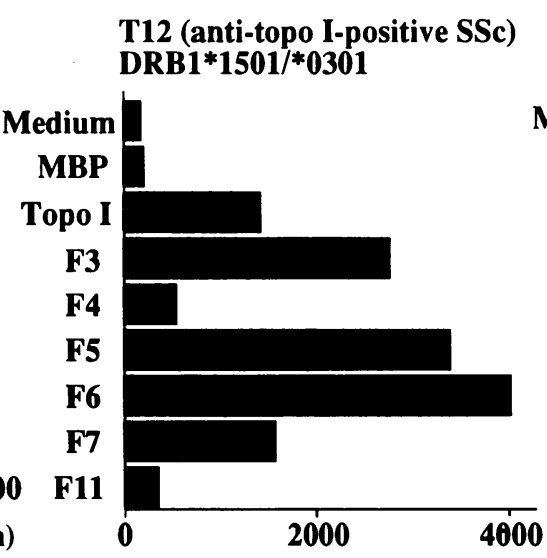

[3H]-thymidine incorporation (cpm)

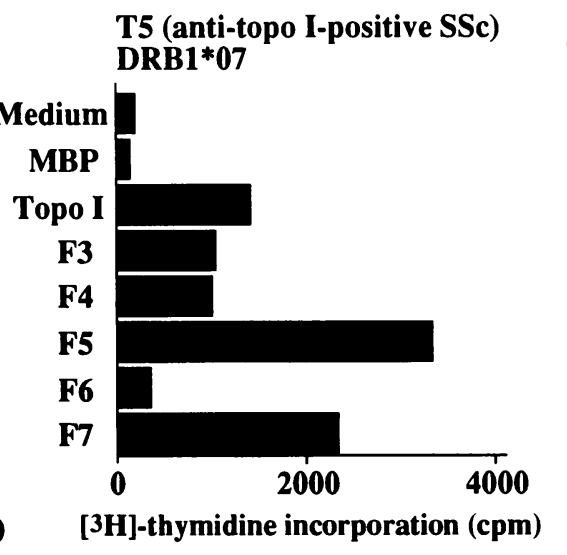

[3H]-thymidine incorporation (cpm)

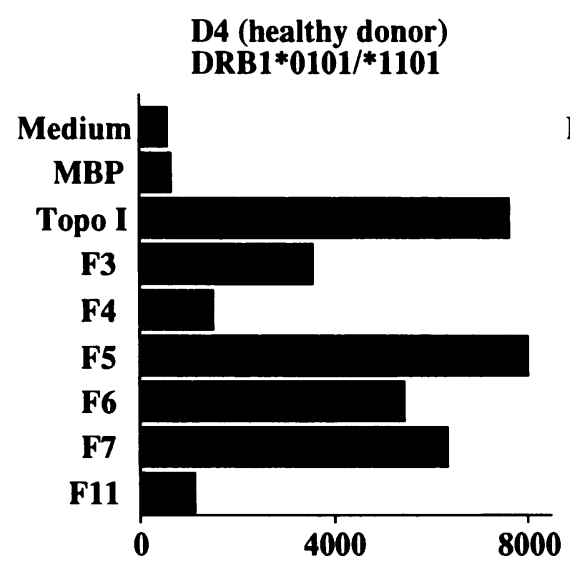

[3H]-thymidine incorporation (cpm)

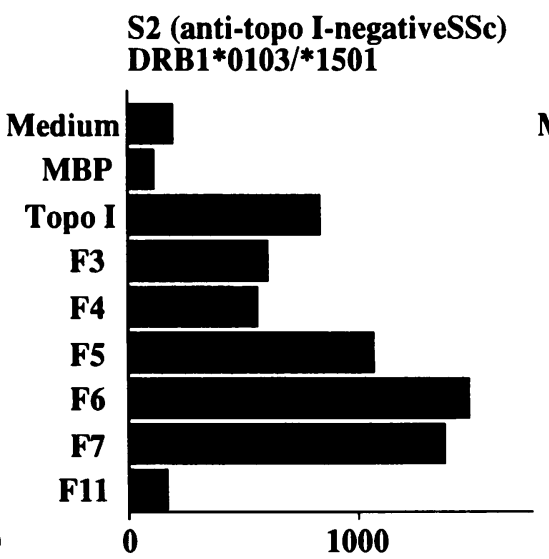

[3H]-thymidine incorporation (cpm)

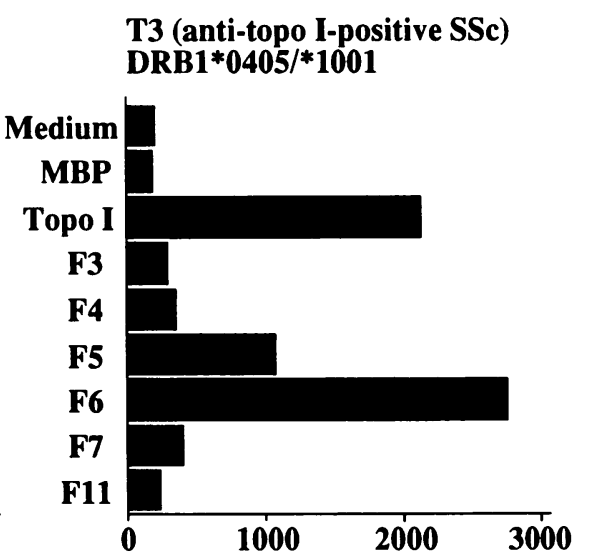

[3H]-thymidine incorporation (cpm)

Figure 8. PBMC proliferative response induced by individual topo I fusion proteins $(F 3, F 4, F 5, F 6, F 7$, and $F 11)$. PBMC (10 5 per well) were stimulated with MBP $(20 \mu \mathrm{g} / \mathrm{ml})$, topo I $(20 \mu \mathrm{g} / \mathrm{ml}), \mathrm{F} 3(9.8 \mu \mathrm{g} / \mathrm{ml}), \mathrm{F} 4(12.2 \mu \mathrm{g} / \mathrm{ml}), \mathrm{F} 5(11.5 \mu \mathrm{g} / \mathrm{ml}), \mathrm{F} 6(12.5 \mu \mathrm{g} / \mathrm{ml}), \mathrm{F} 7(13.4 \mu \mathrm{g} / \mathrm{ml})$, or F11 $(10.2 \mu \mathrm{g} / \mathrm{ml})$ for $7 \mathrm{~d}$. The molar concentration of each fragment was equivalent, based on the estimated molecular weight of the fusion protein. 


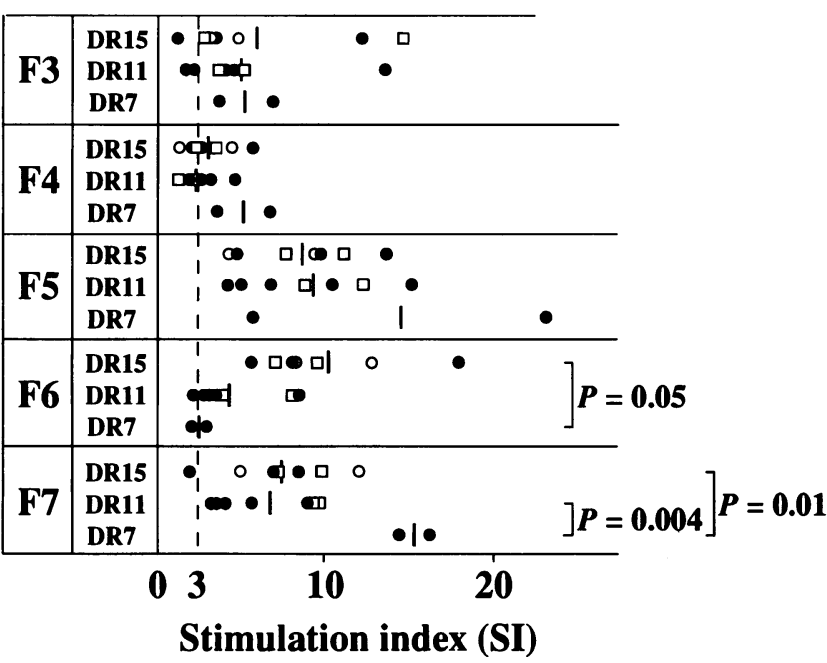

Figure 9. Analysis of topo I fragment-induced PBMC proliferation according to the HLA-DR alleles DR15, DR11, and DR7. PBMC ( $10^{5}$ per well) from 16 responders including $10 \mathrm{SSc}$ patients with anti-topo I antibody (•), 2 SSc patients without anti-topo I antibody (O), and 4 healthy donors $(\square)$ were stimulated with MBP $(20 \mu \mathrm{g} / \mathrm{ml}), \mathrm{F} 3(9.8$ $\mu \mathrm{g} / \mathrm{ml}), \mathrm{F} 4(12.2 \mu \mathrm{g} / \mathrm{ml}), \mathrm{F} 5(11.5 \mu \mathrm{g} / \mathrm{ml}), \mathrm{F} 6(12.5 \mu \mathrm{g} / \mathrm{ml})$, and F7 $(13.4 \mu \mathrm{g} / \mathrm{ml})$ for $7 \mathrm{~d}$. Responders were divided into three groups; individuals having DR15 $(n=7)$, those having DR11 $(n=7)$, and those having DR7 $(n=2)$, who were either homozygotes or heterozygotes with non-DR15, DR11, or DR7 allele. The mean SI level for each group is indicated shown by a solid bar. Differences between mean levels were determined using Student's $t$ test.

DR11/DR7) and three without any of these three HLA-DR types were excluded from this analysis. Although there were no significant differences in the F3-, F4-, and F5-induced proliferative responses among DR15-, DR11-, and DR7-positive responders, SI levels of F6- and F7-induced responses were different among these three groups. The F6-induced responses in DR15-positive individuals were significantly higher than in DR7-positive individuals $(P=0.05)$, and $F 7$-induced responses in DR15- and DR11-positive individuals were lower than in DR7-positive individuals ( $P=0.01$ and 0.004 , respectively). F5-induced proliferative responses were detected in all 19 responders examined. In contrast, only 2 of 13 responders $(15 \%)$ showed a borderline proliferative response against $\mathrm{F} 11$, which contains a 6-amino acid sequence homologous to the retroviral p30 ${ }^{\text {gag }}$ protein $(25)$

\section{Discussion}

In this study, we analyzed the in vitro $\mathrm{T}$ cell proliferative response to topo I in SSc patients and healthy donors. A striking finding was that topo I-induced proliferation was independent of disease and autoantibody status. Characterization of the topo $\mathrm{I}$-induced response revealed that $(a)$ responding $\mathrm{T}$ cells had a CD4+ phenotype; $(b)$ proliferation was dependent on the presence of APCs; $(c)$ the T cell response was mainly restricted by HLA-DR, and to a lesser degree by HLA-DQ; $(d)$ the frequency of responding T cells was 1/9,277-1/24,853; $(e)$ autoreactive T cells recognized multiple T cell epitopes on topo $\mathrm{I}$; and $(f)$ the pattern of $T$ cell epitope recognition was determined, at least in part, by the HLA-DR alleles. These findings were common among anti-topo I-positive SSc patients, anti-topo I-nega- tive SSc patients, and healthy donors. These features of the topo I-specific $\mathrm{T}$ cell response are consistent with previously characterized human $\mathrm{T}$ cell responses against foreign antigens. For example, the frequency of topo I-responding $\mathrm{T}$ cells was similar to previous estimates of $\mathrm{T}$ cells reactive with $\mathrm{Myco}$ bacterium tuberculosis-purified protein derivative $(1 / 1,970$ $1 / 13,982)(22)$. A unique feature of the topo I-induced T cell response was a rapid ( $3 \mathrm{~d}$ ) proliferation seen only in SSc patients positive for anti-topo I antibody. The topo I-specific $\mathrm{T}$ cells identified in our studies probably are involved in antitopo I antibody production, since these $\mathrm{T}$ cells provide help to autologous B cells resulting in anti-topo I antibody production in vitro (Kuwana, M., T. A. Medsger, Jr., and T. M. Wright, unpublished results).

On the basis of the associations between the shared epitopes on the HLA class II alleles and the presence of serum anti-topo I antibody, the HLA-DQ molecule is postulated to play a primary role in anti-topo I antibody production $(11,12)$. In contrast, we have proposed that both HLA-DR and DQ molecules control the autoantibody response against topo I, since the presence of anti-topo I antibody is associated with HLA-DQ alleles and both $\mathrm{B}$ cell epitope reactivity and antibody titer are associated with HLA-DR alleles (12). However, it was difficult to determine which of the HLA-DR and DQ associations was primary in these studies, since HLA-DR and DQ alleles are in strong linkage disequilibrium. In our current study, the topo Ispecific $\mathrm{T}$ cell proliferative response was associated with specific HLA-DR alleles. Furthermore, experiments using antiHLA-DR and anti-HLA-DQ mAbs revealed that the restriction of the topo I-specific $T$ cell response was primarily through HLA-DR, with a minor contribution by HLA-DQ. This pattern of MHC class II restriction is consistent with that of autoreactive $\mathrm{T}$ cells against ribosomal $\mathrm{P} 2$ protein in SLE patients (15).

Since SSc patients and healthy controls with DR 15 or DR 11 showed a similar pattern of $\mathrm{T}$ cell proliferation to topo I fragments, it is possible that APCs bearing DR15 or DR11 bind the common topo I peptides and present these to T cells. PBMC from two healthy donors with DRB $1 * 0801$, but without DR 15 , DR11, or DR7, also showed a proliferative response to topo I and had a pattern of topo I fragment recognition similar to responders with DR15 or DR11 (data not shown). Two DR15 alleles, DRB $1 * 1501$ and $* 1502$, are in linkage disequilibrium with DRB5*0101 and *0102, respectively, and all DR11-positive SSc patients and healthy donors had either DRB1*1101, $* 1103$, or $* 1104$. DRB5 $* 0101$ and $* 0102$ as well as DRB1 $* 1101, * 1103, * 1104$, and $* 0801$ have amino acid residues phenylalanine and aspartic acid at positions 67 and 70 in the DRB $\beta 1$ gene. These positions of the HLA-DR genes are highly polymorphic and are thought to influence peptide-binding because of their location on the surface of the peptidebinding groove (26). Interestingly, these 2 -amino acid residues are included in the shared amino acid sequence that has been reported to be associated with a high anti-topo I antibody titer in Japanese SSc patients (13). APCs bearing DR7 may bind different topo I peptides since topo I responders with DR7 showed a different pattern of topo I fragment-induced $T$ cell proliferation compared with individuals with DR15 or DR11, although only a limited number of DR7-positive individuals were available for analysis. It is likely, therefore, that the polymorphism of the HLA-DR molecules determines the binding to the processed topo I peptides and thus the topo I-specific T cell response. 
The present study indicates that topo I-reactive $\mathrm{T}$ cells are components of the $T$ cell repertoire in many healthy persons and, therefore, that they are not deleted during ontogeny nor are they irreversibly anergic. $T$ cells reactive with self-proteins such as myelin basic protein and insulin have also been found in healthy individuals $(21,27)$. In addition, Hoffman et al. (14) have recently reported the generation of $T$ cell clones specific for human U1 small nuclear ribonucleoprotein (snRNP) from healthy individuals having the HLA-DR alleles associated with anti-U1 snRNP antibody. There are at least two possible explanations for the detection of self-reactive $T$ cells in the peripheral blood of healthy individuals. First, the antigen may have limited tissue distribution and sufficient antigen-derived peptides may not be presented in the thymus or the periphery resulting in a lack of $\mathrm{T}$ cell clonal deletion and/or anergy (immunologic ignorance). An argument against this model is that the topo I protein appears to be ubiquitously distributed and thymic extracts have traditionally been used as antigens for detection of anti-topo I antibodies (7). Under normal circumstances, however, peptides derived from topo I may not be processed and presented efficiently via the MHC class II pathway since it is a nuclear protein that is extremely sensitive to proteolytic degradation (28, and Kuwana, M., and T. M. Wright, unpublished observation). Second, it has been recently proposed that $\mathrm{T}$ cells responsive to minor or cryptic determinants, i.e., those not usually generated during in vivo processing, can evade tolerance because of the relatively low amounts of peptides suitable for binding to HLA molecule after in vivo processing of the antigen (29). These autoreactive $T$ cells may become pathogenic if the cryptic determinant is revealed (30), and the immune response may subsequently diversify to recognize other areas on the same autoantigen to which there was previous $T$ cell tolerance $(31,32)$. It was also reported that autoreactive $T$ cells can be activated by artificially processed peptides, which might express cryptic determinants $(33,34)$. It is possible that the recombinant topo I fusion proteins used as antigens in our in vitro $\mathrm{T}$ cell proliferation assays were processed differently than native topo I, resulting in the generation of topo I peptides containing cryptic epitopes that are not formed normally in vivo. Our findings, therefore, are consistent with both models of autoantigen recognition since $\mathrm{T}$ cells from anti-topo I-positive SSc patients as well as anti-topo I-negative SSc patients and healthy donors with the appropriate HLA class II molecules were able to respond to topo I.

Our results suggest that topo I-specific $T$ cells are activated in anti-topo I-positive SSc patients, but not in anti-topo Inegative SSc patients and healthy donors. The mechanism of antigen exposure which resulted in the activation of these $T$ cells in vivo is unknown. One possibility is that cryptic determinants on topo I were revealed in anti-topo I-positive SSc patients due to factors that may affect normal processing of topo I such as the formation of complexes with other proteins or posttranslational modifications of topo I itself. In this regard, it has been shown recently that autoantibody to the p53 tumor suppressor protein was induced in mice immunized with complexes of murine p53 and SV40 large T antigen, but not in mice immunized with either protein separately (35). Topo I activity in host cells is known to be necessary for the replication and transcription of several viral genomes, such as adenovirus (36), SV40 $(37,38)$, herpes simplex virus (39), EBV (40), and HIV (41). Since topo I binds tightly to viral proteins and/or DNA during viral replication and transcription $(38,41)$, $\mathrm{T}$ cell auto- immunity may be initiated by the complex of topo I with certain viral proteins. Another possibility is that, similar to the recent observations regarding the localization of lupus autoantigens in UVB-treated keratinocytes (42), topo I protein in a native or altered form may be clustered in blebs at the surface of apoptotic cells. It is known that a number of free radical - and proteinaseinduced modifications of proteins $(43,44)$ occur during apoptosis. Perhaps these site-specific modifications result in the generation of unique peptide fragments and reveal potentially cryptic determinants. A third possibility is that anti-topo Ipositive patients have been exposed to a foreign protein that cross-reacts with topo I. It was reported that autoreactive T cells and autoantibodies to self-snRNP can be generated in normal mice by coimmunization with a mixture of self- and foreign snRNP (45). The mechanism is thought to be the generation of cross-reactive $B$ cells, initially primed by foreign snRNP serving as a molecular mimic, that then bind, process, and present self-snRNP with the activation of autoreactive $T$ cells. This hypothesis is supported by our recent identification of a major $\mathrm{T}$ cell epitope on topo I (Kuwana, M., and T. M. Wright, unpublished observation) that is located in a region that is highly conserved among all topo I proteins for which sequence is available, including human (46), mouse (47), yeast (48), Shope fibroma virus (49), and vaccinia virus (50). Furthermore, the nucleocapsid proteins of some retroviruses have been shown to have topo I enzymatic activity and cross-react with anti-topo I autoantibody in SSc sera (51).

Based on our results, it is likely that the production of antitopo I antibody in a subset of SSc patients is the result of a combination of factors that include $(a)$ certain HLA-DR alleles; (b) increased presentation of topo I-derived peptides by one of a number of mechanisms described above; and $(c)$ the activation of B cells. In conclusion, our studies provide support for the antigen-driven hypothesis for the production of autoreactive $T$ cells and autoantibodies and further define the relationship between specific MHC class II alleles and anti-topo I antibody in SSc.

\section{Acknowledgments}

We thank Gigi Allias, R.N. and Carol Blair, R.N. for coordinating the blood sample collection, Jeffrey Anderson for the clinical data analyses, Nanette Guyer for expert technical assistance, Dr. Olivera Finn for her helpful advice, Dr. Susan McCarthy for assisting with the FACS analysis, and Dr. Hidetoshi Inoko for numerous thoughtful suggestions.

This work was supported by grants from the Arthritis Foundation, West Pennsylvania Chapter (Shoemaker Fund); the RGK Foundation; and National Institutes of Health grant AR-21393.

\section{References}

1. Medsger, T. A., Jr. 1993. Systemic sclerosis (scleroderma), localized forms of scleroderma, and calcinosis. In Arthritis and Allied Conditions. 12th ed. D. J. McCarty and W. J. Koopman, editors. Lea \& Febiger, Philadelphia, PA. 12531292.

2. Okano, Y., V. D. Steen, and T. A. Medsger, Jr. 1993. Autoantibody reactive with RNA polymerase III in systemic sclerosis. Ann. Intern. Med. 119:10051013.

3. Kuwana, M., J. Kaburaki, T. Mimori, T. Tojo, and M. Homma. 1993. Autoantibody reactive with three classes of the RNA polymerases in sera from patients with systemic sclerosis. J. Clin. Invest. 91:1399-1404.

4. Steen, V. D., D. L. Powell, and T. A. Medsger, Jr. 1988. Clinical correlations and prognosis based on serum autoantibodies in patients with progressive systemic sclerosis. Arthritis Rheum. 31:196-203.

5. Kuwana, M., Y. Okano, J. Kaburaki, T. Tojo, and M. Homma. 1994. 
Clinical and prognostic associations based on serum antinuclear antibodies in Japanese patients with systemic sclerosis. Arthritis Rheum. 37:75-83.

6. Shero, J. H., B. Bordwell, N. F. Rothfield, and W. C. Earnshaw. 1986. High titer of autoantibodies to topoisomerase I (Scl-70) in sera from scleroderma patients. Science (Wash. DC). 231:737-740.

7. Douvas, A. S., M. Achten, and E. M. Tan. 1979. Identification of nuclear protein ( $\mathrm{Scl}-70)$ as a unique target of human antinuclear antibodies in scleroderma. J. Biol. Chem. 254:10514-10522.

8. Kuwana, M., Y. Okano, J. Kaburaki, T. Tojo, and T. A. Medsger, Jr. 1994. Racial differences in the distribution of systemic sclerosis-related serum antinuclear antibodies. Arthritis Rheum. 37:902-906.

9. Kuwana, M., J. Kaburaki, T. Mimori, T. Tojo, and M. Homma. 1993. Autoantigenic epitopes on DNA topoisomerase I: clinical and immunogenetic associations in systemic sclerosis. Arthritis Rheum. 36:1406-1413.

10. Kuwana, M., T. A. Medsger, Jr., and T. M. Wright. 1995. Detection of anti-DNA topoisomerase I antibody by an enzyme-linked immunosorbent assay using overlapping recombinant polypeptides. Clin. Immunol. Immunopathol. In press.

11. Reveille, J. D., E. Durban, M. J. MacLeod-St. Clair, R. Goldstein, R. Moreda, R. D. Altman, and F. C. Arnett. 1992. Association of amino acid sequences in the HLA-DQB1 first domain with the antitopoisomerase I autoantibody response in scleroderma (progressive systemic sclerosis). J. Clin. Invest. 90:973980.

12. Morel, P. A., H. J. Chang, J. W. Wilson, C. Conte, S. L. Saidman, J. D. Bray, D.J. Tweardy, and T. A. Medsger, Jr. 1994. Severe systemic sclerosis with anti-topoisomerase I antibodies is associated with an HLA-DRw11 allele. Hum. Immunol. 40:101-110.

13. Kuwana, M., J. Kaburaki, Y. Okano, H. Inoko, and K. Tsuji. 1993. The HLA-DR and DQ genes control the autoimmune response to DNA topoisomerase I in systemic sclerosis (scleroderma). J. Clin. Invest. 92:1296-1301.

14. Hoffman, R. W., Y. Takeda, G. C. Sharp, D. R. Lee, D. L. Hill, H Kaneoka, and C. W. Caldwell. 1993. Human T cell clones reactive against U-small nuclear ribonucleoprotein autoantigens from connective tissue disease patients and healthy individuals. J. Immunol. 151:6460-6469.

15. Crow, M. K., G. DelGiudice-Asch, J. B. Zehetbauer, J. L. Lawson, N Brot, H. Weissbach, and K. B. Elkon. 1994. Autoantigen-specific T cell proliferation induced by the ribosomal $\mathrm{P} 2$ protein in patients with systemic lupus erythematosus. J. Clin. Invest. 94:345-352.

16. Rajagopalan, S., T. Zordan, G. C. Tsokos, and S. K. Datta. 1990. Pathogenic anti-DNA antibody-inducing $\mathrm{T}$ helper cell lines from patients with active lupus nephritis: isolation of CD4-8-T helper cell lines that express the $\gamma \delta$ T-cell antigen receptor. Proc. Natl. Acad. Sci. USA. 87:7020-7024.

17. Subcommittee for Scleroderma Criteria of the American Rheumatism Association Diagnostic and Therapeutic Criteria Committee. 1980. Preliminary criteria for the classification of systemic sclerosis (scleroderma). Arthritis Rheum. 23:581-590.

18. Lerner, M. R., and J. A. Steitz. 1979. Antibodies to small nuclear RNAs complexed with proteins are produced by patients with systemic lupus erythematosus. Proc. Natl. Acad. Sci. USA. 76:5495-5499.

19. Maina, C. V., P. D. Riggs, A. G. Grandea III, B. E. Slatko, L. S. Moran, J. A. Tagliamonte, L. A. McReynolds, and C. Guan. 1988. A vector to express and purify foreign proteins in Escherichia coli by fusion to, and separation from, maltose-binding protein. Gene. 74:365-373.

20. Funderud, S., K. Nustad, T. Lea, F. Vartdal, G. Gaudernack, P. Stenstad, and J. Ugelstad. 1987. Fractionation of lymphocytes by immunomagnetic beads. In Lymphocytes: A Practical Approach. G. G. Klaus, editor. IRL Press, Oxford, UK. 55-65.

21. Ito, Y. M. Nieda, Y. Uchigata, M Nishimura, K. Tokunaga, S. Kuwata, F. Obata, K. Tadokoro, Y. Hirata, Y. Omori, and T. Juji. 1993. Recognition of human insulin in the context of HLA-DRB $1 * 0406$ products by T cells of insulin autoimmune syndrome patients and healthy donors. J. Immunol. 151:5770-5776.

22. Brett, S. J., A. E. Kingston, and M. J. Colston. 1987. Limiting dilution analysis of the human $T$ cell response to mycobacterial antigens from BCG vaccinated individuals and leprosy patients. Clin. Exp. Immunol. 68:510-520.

23. Inoko, H., A. Ando, M. Ito, and K. Tsuji. 1986. Southern hybridization analysis of DNA polymorphism in the HLA-D region. Hum. Immunol. 16:304313 .

24. Inoko, H., and M. Ota. 1993. PCR-RFLP. In Handbook of HLA Typing Techniques. K. M. Hui and J. L. Bidwell, editors. CRC Press, Boca Raton, FL. 9-70.

25. Maul, G. G., S. A. Jimenez, E. Riggs, and D. Ziemnicka-Kostula. 1989. Determination of an epitope of the diffuse systemic sclerosis marker antigen DNA topoisomerase I: sequence similarity with retroviral $\mathrm{p} 30^{\mathrm{gag}}$ protein suggests possible cause for autoimmunity in systemic sclerosis. Proc. Natl. Acad. Sci. USA 86:8492-8496.

26. Brown, J. H., T. S. Jardetsky, J. C. Gorga, L. J. Stern, R. G. Urban, J. L.
Strominger, and D. C. Wiley. 1993. Three-dimensional structure of the human class II histocompatibility antigen HLA-DR1. Nature (Lond.). 364:33-39.

27. Burns, J., A. Rosenzweig, B. Zweiman, and R. P. Lisak. 1983. Isolation of myelin basic protein-reactive T-cell lines from normal human blood. Cell. Immunol. 81:435-440.

28. Samuels, D. S., and N. Shimizu. 1994. The predominant form of mammalian DNA topoisomerase $\mathrm{I}$ in vivo has a molecular mass of $100 \mathrm{kDa} . \mathrm{Mol}$. Biol. Rep. 19:99-103.

29. Gammon, G., and E. Sercarz. 1989. How some T cells escape tolerance induction. Nature (Lond.). 342:183-185.

30. Lipham, W. J., T. M. Redmond, H. Takahashi, J. A. Berzofsky, B. Wiggert, G. J. Chader, and I. Gery. 1991. Recognition of peptides that are immunogenic but cryptic: mechanisms that allow lymphocytes sensitized against cryptic peptides to initiate pathogenic autoimmune processes. J. Immunol. 146:3757-3762.

31. Lehmann, P. V., T. Forsthuber, A. Miller, and E. E. Sercarz. 1992. Spreading of T-cell autoimmunity to cryptic determinants of an autoantigen. Nature (Lond.). 358:155-157.

32. Fatenejad, S., M. J. Mamula, and J. Craft. 1993. Role of intermolecular/ intrastructural B- and T-cell determinants in the diversification of autoantibodies to ribonucleoprotein particles. Proc. Natl. Acad. Sci. USA. 90:12010-12014.

33. Mamula, M. J. 1993. The inability to process a self-peptide allows autoreactive T cells to escape tolerance. J. Exp. Med. 177:567-571.

34. Oki, A., and E. Sercarz. 1985. T cell tolerance studied at the level of antigenic determinants. I. Latent reactivity to lysozyme peptides that lack suppressogenic epitopes can be revealed in lysozyme-tolerant mice. J. Exp. Med. 161:897-911.

35. Dong, X., K. J. Hamilton, M. Satoh, J. Wang, and W. H. Reeves. 1994. Initiation of autoimmunity to the $\mathrm{p} 53$ tumor suppressor protein by complexes of p53 and SV40 large T antigen. J. Exp. Med. 179:1243-1252.

36. Wong, M. L., and M. T. Hsu. 1990. Involvement of topoisomerases in replication, transcription, and packaging of the linear adenovirus genome. J. Virol. 64:691-699.

37. Champoux, J. J. 1992. Topoisomerase I is preferentially associated with normal SV40 replicative intermediates, but is associated with both replicating and nonreplicating SV40 DNAs which are deficient in histones. Nucleic Acid Res. 20:3347-3352.

38. Mann, K. 1993. Topoisomerase activity is associated with purified SV40 T antigen. Nucleic Acid Res. 21:1697-1704.

39. Yamada, Y., N. Yamamoto, K. Maeno, and Y. Nishiyama. 1990. Role of DNA topoisomerase I in the replication of herpes simplex virus type 2. Arch. Virol. 110:121-127.

40. Kawanishi, M. 1993. Topoisomerase I and II activities are required for Epstein-Barr virus replication. J. General Virol. 74:2263-2268.

41. Jardine, D., G. Tachedjian, S. Locarnini, and C. Birch. 1993. Cellular topoisomerase I activity associated with HIV-1. AIDS Res. Hum. Retroviruses. 9:1245-1250.

42. Casciola-Rosen, L. A., G. Anhalt, and A. Rosen. 1994. Autoantigens targeted in systemic lupus erythematosus are clustered in two populations of surface structures on apoptotic keratinocytes. J. Exp. Med. 179:1317-1330.

43. Davies, K. J. A. 1987. Protein damage and generation by oxygen radicals. I. General aspects. J. Biol. Chem. 262:9895-9901.

44. Wilff, S. P., and R. T. Dean. 1986. Fragmentation of proteins by free radicals and its effect on their susceptibility to enzymic hydrolysis. Biochem. $J$. 234:399-403.

45. Mamula, M. J., S. Fatenejad, and J. Craft. 1994. B cells process and present lupus autoantigens that initiate autoimmune T cell response. J. Immunol. 152:1453-1461.

46. D'Arpa, P., P. S. Machlin, H. Ratrie, N. F. Rothfield, D. W. Cleveland, and W. C. Earnshaw. 1988. cDNA cloning of human DNA topoisomerase I: catalytic activity of a 67.6-kDa carboxyl-terminal fragment. Proc. Natl. Acad. Sci. USA. 85:2543-2547.

47. Koiwai, O., Y. Yasui, Y. Sakai, T. Watanabe, K. Ishii, S. Yanagihara, and T. Andoh. 1993. Cloning of the mouse cDNA encoding DNA topoisomerase I and chromosomal location of the gene. Gene. 125:211-216.

48. Thrash, C., A. T. Bankier, B. G. Barrell, and R. Sternglanz. 1985. Cloning, characterization, and sequence of the yeast DNA topoisomerase I gene. Proc. Natl. Acad. Sci. USA. 82:4374-4378.

49. Upton, C., A. Opgenorth, P. Traktman, and G. McFadden. 1990. Identification and DNA sequence of the Shope fibroma virus DNA topoisomerase gene. Virology. 176:439-447.

50. Shuman, S., and B. Moss. 1987. Identification of a vaccinia virus gene encoding a type I DNA topoisomerase. Proc. Natl. Acad. Sci. USA. 84:74787482.

51. Priel, E., S. D. Showalter, M. Roberts, S. Oroszlan, S. Segal, M. Aboud and D. G. Blair. 1990. Topoisomerase I activity associated with human immunodeficiency virus (HIV) particles and equine infectious anemia virus core. $E M B O$ (Eur. Mol. Biol. Organ.) J. 9:4167-4172. 